International Conference on Business Research

University of Moratuwa, Moratuwa, Sri Lanka

June 13, 2018, 59-69.

DOI: https://doi.org/10.31705/ICBR.2018.8

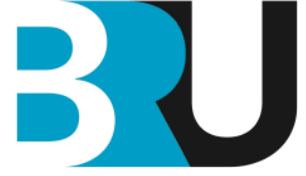

BUSINESS RESEARCH UNIT

FACULTY OF BUSINESS

UNIVERSITY OF MORATUWA

\title{
Critical success factors of international technology transfer: a case of the Norochcholai Coal Power Project in Sri Lanka
}

\author{
W. Jayaratne ${ }^{1 *}$, S. W. S. B. Dasanayaka² and D. Mudalige ${ }^{2}$ \\ ${ }^{1}$ Commercial WPS-1, Ceylon Electricity Board, Sri Lanka \\ ${ }^{2}$ Department of Industrial Management, Faculty of Business, University of \\ Moratuwa, Sri Lanka
}

Success and failure of Norochcholai Coal Power Plant (NCPP) in terms of technology transfer aspect is a debatable subject in Sri Lankan energy scene. This NCPP is the country's largest coal power based energy generator which came into the operation in three steps of 300MW as Phase 1 in the year 2011, Phase II in year 2013 and Phase III in year 2014. The total investment of the project was 1.35 Billion USD and out of which 450Million USD was received as a soft loan from the Export and Import (EXIM) Bank of China. The project construction was undertaken by the China Machinery Engineering Corporation (CMEC) of China and it successfully came in to the light amidst the enormous amount of objections coming from different environmental and social pressure groups. After few years of operation, this power plant failed several times causing thousand hours of generation loss while incurring nearly 6.5 Billion Rupees reduction of income to the national economy due to the unavailability of the plant as per the Ceylon Electricity Board (CEB) Annual Report 2015. In consequent to this, most of the expectations diluted and the negative impacts of environmental, social and cultural factors were highlighted by the media several times. Therefore, the identification of critical success factors during the technology transfer stage of this power plant is of extremely important subject. The main methodology of this study is secondary data, complements with interviews with various stake holders. It reviewed 34 success factors of technology transfer and found that 14 factors are critical success factors in terms of technology transfer. The recommendations of this study can be used as guides for designing suitable mechanism for technology transfer aspect of incoming coal power plants in Sri Lanka and other countries of similar background. 
Keywords: coal power, technology transfer, critical success factors, Norochcholai Coal Power Plant; NCPP.

\section{Background}

Technology is the life blood for any nation to achieve competitiveness, economic growth and survival but, technology prevails mostly with developed nations. Due to higher investment on research and development activities, those countries have reached the state of the art technology to run the entire world. A successful technology transfer involves many levels of complexity. It necessitates efficient and rational design, continuous raw material flowing strategy, balanced business model that synchronizes with existing terms of contracts and different commercial conditions in the country. The sole aim of technology transfer is to maximize the profit and minimize the cost. The achievement of new technology will depend on three major components. Those are the firm's ability to develop the technology by their own, having joint research and development (R\&D) with other party or transferring it from any other organization in the same country which has already harnessed the particular technology. When internal development of technology takes longer time due to lack of expertise, heavy capital cost or any other matter, it is preferred to go for technology transfer from another country or from any other institution locally.

\subsection{Research objectives}

This study is focused on following objectives;

i) To explore the critical success factors on international technology transfer on Norochcholai Coal Power Plant (NCPP) in Sri Lanka

ii) To derive policies and guide lines for effective technology transfer on future coal power plants in Sri Lanka.

\subsection{Research questions}

i) What are the issues prevailing with respect to poor, inappropriate technology transfer on NCPP in Sri Lanka?

ii) What are the important factors of technology transfer with respect to NCPP in Sri Lanka?

iii) What are the policies and guide lines needed in future coal power stations in Sri Lanka?

\section{Literature review}

Ramanathan (1994) explains that there are three major components of technology. The techniques which involve with the equipment, the special knowhow which requires to operate the equipment, the mechanism which enables the administration of the entire system. Coal as an energy resource is widely used for electricity generation in many parts of the 
world. It gives very low operation and maintenance cost despite higher initial cost on international technology transfer. According to Hussain (2008), the successfulness of technology transfer in CEB is still under the microscope and further improvements prevail. Specially, efficient design and operational mechanisms have not been studied thoroughly and as a result an effective technology transfer has not been harnessed successfully. According to the findings of Abobaker (2015), there are two components of technology transfer which includes manageable and unmanageable factors. The manageable factors are human skills, government policy, level of technology and education and training. Where as unmanageable factors are environment level of host country, climate and availability of natural resources.

\subsection{What is technology transfer?}

International technology transfer is defined as the mechanism of exchanging the new knowledge between two institutions or two countries with the benefit to both party (Khan, 2005). When it comes to coal power generation technology transfer, it is expected to generate more electricity with a lowest unit cost. According to Pazhand (2009), present share of coal in world power generation is $45 \%$. Pazhand (2009), further explains that technology transfer in this field involve sharing of skills, knowledge, methods and mechanisms within the country and between countries. However, still there exists the need for improvements in technology transfer. According to Bell (1997), technology transfer involves the transfer of many disciplines including the skills, know-how and mechanisms to run the entire system long lasting.

\subsection{Research gap}

According to Hussain (2008), the successfulness of technology transfer in CEB is not at its optimum level due to various failures experienced in the existing systems. The failure of Bowatenna hydro power station, recent failure of Kukule Ganaga hydro power station and frequent failures in Norochcolai coal power plant (NCPP) are the major examples for such ineffective technology transfer in Sri Lanka. Therefore, it is obvious that still improvements opportunities may prevail in technology transfer aspects with respect to those projects. Therefore, research gap exists in this field. Pazhand (2009), has found that there is considerable research gap prevails in technology transfer mechanisms of coal power generation within developed and developing countries. Many countries have achieved just the process of converting the energy from one form of matter to another with the existing financial capability, but not the whole system of activities to be followed on entire horizon. That is the reason for prevailing gaps in this field. Hussain (2008) has found that technology converting and acquiring capabilities of CEB are above average while vending, modifying and innovating capabilities at secondary level. Further, the researcher has found that technoware, humanware specific inforware (HSI), orgaware specific infoware (OSI) were above average 
level while other technology components like humanware, orgaware and technoware specific infoware (TSI) are at primitive level and prevail a knowledge gap.

\section{Methodology and research design}

A quantitative research methodology was used in this study. Technology can be transferred even from institution to institution within the same country. In this study, technology transfer from technology rich country to just developing country is considered for our convenience. The effectiveness of the technology transfer process will be moderated by different factors inherent to the transferor's and transferee's social, environmental and legislative constraints. This research is composed of extensive literature survey, a structured questionnaire survey placed on industry experts, energy consultants, academic professionals, environmentalists and staff of the NCPP. Questionnaire was prepared based on Table 1 and thereby unearthed the 34 identifiers on 04 concepts and 20 indicators with the help of multiple choice questions based on Rensis Likert scale which is composed of 5 points and the highest is the "strongly agree" and which gives 5 weight and the lowest is "strongly disagree", which gives 1 weight. In between, weight three is given to neutral position. Weight 4 is given for "agree" and weight 2 is given for "disagree" situation.

\subsection{Hypothesis}

In this study, 34 factors are selected in principle and tested for ascertaining the critical success factors of technology transfer specially focused on NCPP. Twenty (20) hypotheses from H1 to H20 have been tested within this study and given in Table 1 . The critical success factors connected with international technology transfer have been derived with $95 \%$ confidence level. There are 20 indicators for identified 04 constructs which explain the international technology transfer to develop NCPP.

\subsection{Data collection and questionnaire}

A structured questionnaire was designed to cover the demographic details and actual responses on different indicators identified as major factors (Tan, 1996). Accordingly, 12 questions on demographic data and 45 questions on success factors with respect to NCPP were inquired from 100 respondents out of which 03- energy consultants, 10environmentalists, 30 staff members of NCPP, 40Industrialists/residents/scientists and $05=$ other professionals, 05 Chinese engineers and 07 - major electricity consumers. Total percentage of the receiving of completed answers was $83 \%$. 
International Conference on Business Research

Table 1. Success factors to be transferred from transferor to transferee

\begin{tabular}{|c|c|c|c|c|}
\hline Concept & Indicator & & $\begin{array}{l}\text { riable Identifier and } \\
\text { Measure }\end{array}$ & $\begin{array}{l}\text { Measurement } \\
\text { Source }\end{array}$ \\
\hline \multirow{15}{*}{$\begin{array}{l}\text { Technoware } \\
\text { (C1) }\end{array}$} & \multirow{4}{*}{$\begin{array}{l}\text { Devices (H1) : Devices } \\
\text { play major role in } \mathrm{T} / \mathrm{T}\end{array}$} & $\mathrm{X}_{1}$ & Quality of devices & \multirow[t]{9}{*}{ Khan (2005) } \\
\hline & & $\mathrm{X}_{2}$ & Cost of devices & \\
\hline & & $\mathrm{X}_{3}$ & Life time of devices & \\
\hline & & $\mathrm{X}_{4}$ & Reliability of devices & \\
\hline & \multirow{4}{*}{$\begin{array}{l}\text { Equipment (H2): } \\
\text { Equipment play major role } \\
\text { in } \mathrm{T} / \mathrm{T}\end{array}$} & $\mathrm{X}_{5}$ & Quality of Equipment & \\
\hline & & $\mathrm{X}_{6}$ & Cost of Equipment & \\
\hline & & $\mathrm{X}_{7}$ & $\begin{array}{l}\text { Life time of } \\
\text { Equipment }\end{array}$ & \\
\hline & & $\mathrm{X}_{8}$ & $\begin{array}{l}\text { Reliability of } \\
\text { Equipment }\end{array}$ & \\
\hline & \multirow{2}{*}{$\begin{array}{l}\text { Machinery (H3): } \\
\text { Machinery play major role } \\
\text { in T/T }\end{array}$} & $\mathrm{X}_{9}$ & Quality of machinery & \\
\hline & & $\mathrm{X}_{10}$ & Cost of machinery & \multirow{2}{*}{$\begin{array}{l}\text { Martyniuk, } \\
\text { Jain \& Stone, } \\
\text { (2003) }\end{array}$} \\
\hline & $\begin{array}{l}\text { Scale of operation }(\mathrm{H} 4) \text { : } \\
\text { Scale of operation play } \\
\text { major role in } \mathrm{T} / \mathrm{T}\end{array}$ & $\mathrm{X}_{11}$ & $\begin{array}{l}\text { Appropriateness of } \\
\text { scale of operation }\end{array}$ & \\
\hline & $\begin{array}{l}\text { Scope of outputs (H5): } \\
\text { Scope of operation play } \\
\text { major role in } \mathrm{T} / \mathrm{T}\end{array}$ & $\mathrm{X}_{12}$ & $\begin{array}{l}\text { Appropriateness of } \\
\text { scope of operation }\end{array}$ & \multirow[t]{4}{*}{$\begin{array}{l}\text { Dasanayake \& } \\
\text { Jayarathna } \\
\text { (2012) }\end{array}$} \\
\hline & $\begin{array}{l}\text { Quality of outputs (H6): } \\
\text { Quality of outputs play } \\
\text { major role in T/T }\end{array}$ & $\mathrm{X}_{13}$ & $\begin{array}{l}\text { Appropriateness of } \\
\text { quality of output }\end{array}$ & \\
\hline & $\begin{array}{l}\text { Safety concern (H7) : } \\
\text { Safety concern play major } \\
\text { role in } \mathrm{T} / \mathrm{T}\end{array}$ & $\mathrm{X}_{14}$ & $\begin{array}{l}\text { Appropriateness of } \\
\text { safety issues }\end{array}$ & \\
\hline & $\begin{array}{l}\text { Environmental soundness } \\
\text { of operation (H8): } \\
\text { Environmental soundness } \\
\text { of operation has major } \\
\text { role in T/T }\end{array}$ & $\mathrm{X}_{15}$ & $\begin{array}{l}\text { Environmental } \\
\text { soundness of } \\
\text { operation }\end{array}$ & \\
\hline \multirow[t]{8}{*}{$\begin{array}{l}\text { Humanware } \\
\text { (C2) }\end{array}$} & \multirow{4}{*}{$\begin{array}{l}\text { Skills (H9) : Skills of } \\
\text { transferor/Transferee and } \\
\text { their staff play major role } \\
\text { in T/T }\end{array}$} & $\mathrm{X}_{16}$ & Transferor skills & $\begin{array}{c}\text { Purushotham } \\
\text { (2015) }\end{array}$ \\
\hline & & & $\begin{array}{l}\text { Transferor } \\
\text { supporting staff skills }\end{array}$ & $\begin{array}{c}\text { Bell et. al } \\
(1997)\end{array}$ \\
\hline & & $\mathrm{X}_{18}$ & Transferee skills & $\begin{array}{c}\text { Dameno \& } \\
\text { Lopez (2015) }\end{array}$ \\
\hline & & $\mathrm{X}_{19}$ & $\begin{array}{l}\text { Transferee } \\
\text { supporting staff skills }\end{array}$ & $\begin{array}{c}\text { Dasanayake \& } \\
\text { Jayarathna } \\
(2012)\end{array}$ \\
\hline & \multirow{2}{*}{$\begin{array}{l}\text { Knowledge (H10): } \\
\text { Knowledge of } \\
\text { Transferor/Transferee } \\
\text { play major role in } \mathrm{T} / \mathrm{T}\end{array}$} & & $\begin{array}{l}\text { Transferor } \\
\text { knowledge }\end{array}$ & \multirow{2}{*}{$\begin{array}{l}\text { Martyniuk, } \\
\text { Jain \& Stone, } \\
\text { (2003) }\end{array}$} \\
\hline & & $\mathrm{X}_{21}$ & $\begin{array}{l}\text { Transferee } \\
\text { knowledge }\end{array}$ & \\
\hline & \multirow{2}{*}{$\begin{array}{l}\text { Expertise (H11) : } \\
\text { Expertise of } \\
\text { Transferor/Transferee } \\
\text { play major role in } \mathrm{T} / \mathrm{T}\end{array}$} & $\mathrm{X}_{22}$ & Transferor expertise & $\begin{array}{c}\text { Dasanayake \& } \\
\text { Jayarathna } \\
(2012)\end{array}$ \\
\hline & & $\mathrm{X}_{23}$ & Transferee expertise & $\begin{array}{l}\text { Dasanayaka \& } \\
\text { Sadana (2010) }\end{array}$ \\
\hline
\end{tabular}


Table 1. continued.

\begin{tabular}{|c|c|c|c|c|}
\hline Concept & Indicator & & $\begin{array}{l}\text { riable Identifier and } \\
\text { Measure }\end{array}$ & $\begin{array}{l}\text { Measurement } \\
\text { Source }\end{array}$ \\
\hline \multirow[t]{6}{*}{$\begin{array}{l}\text { Orgaware } \\
\text { (C3) }\end{array}$} & $\begin{array}{l}\text { Methods (H12) : } \\
\text { Effectiveness of methods } \\
\text { play major role in } \mathrm{T} / \mathrm{T}\end{array}$ & $\mathrm{X}_{24}$ & $\begin{array}{l}\text { Effectiveness of } \\
\text { methods }\end{array}$ & \multirow{6}{*}{$\begin{array}{c}\text { Abobaker } \\
(2015) \\
\text { Kumaraswamy } \\
(2003) \\
\text { Dasanayake \& } \\
\text { Sadana (2010) }\end{array}$} \\
\hline & $\begin{array}{l}\text { Techniques (H13) : } \\
\text { Effectiveness of } \\
\text { techniques play major role } \\
\text { in } \mathrm{T} / \mathrm{T}\end{array}$ & $\mathrm{X}_{25}$ & $\begin{array}{l}\text { Effectiveness of } \\
\text { techniques }\end{array}$ & \\
\hline & \multirow{2}{*}{$\begin{array}{l}\text { Networking (H14) : } \\
\text { Effectiveness of } \\
\text { Transferor/Transferee } \\
\text { networking play major } \\
\text { role in T/T }\end{array}$} & $\mathrm{X}_{26}$ & $\begin{array}{l}\text { Effectiveness of } \\
\text { transferor networks }\end{array}$ & \\
\hline & & $\mathrm{X}_{27}$ & $\begin{array}{l}\text { Effectiveness of } \\
\text { transferee networks }\end{array}$ & \\
\hline & \multirow{2}{*}{$\begin{array}{l}\text { Practices (H15): } \\
\text { Effectiveness of } \\
\text { Transferor/Transferee } \\
\text { practices play major role } \\
\text { in T/T }\end{array}$} & $\mathrm{X}_{28}$ & $\begin{array}{l}\text { Effectiveness of } \\
\text { transferor practices }\end{array}$ & \\
\hline & & $\mathrm{X}_{29}$ & $\begin{array}{l}\text { Effectiveness of } \\
\text { transferee practices }\end{array}$ & \\
\hline \multirow[t]{5}{*}{$\begin{array}{l}\text { Infoware } \\
\text { (C4) }\end{array}$} & $\begin{array}{l}\text { Design parameters }(\mathrm{H} 16): \\
\text { Design parameters play } \\
\text { major role in } \mathrm{T} / \mathrm{T}\end{array}$ & $\mathrm{X}_{30}$ & $\begin{array}{l}\text { Effectiveness of } \\
\text { design parameters }\end{array}$ & $\begin{array}{c}\text { Abbaslu \& } \\
\text { Yaghoubipoor } \\
(2015) \\
\end{array}$ \\
\hline & $\begin{array}{l}\text { Specifications }(\mathrm{H} 17): \\
\text { Specification play major } \\
\text { roles in } \mathrm{T} / \mathrm{T}\end{array}$ & $\mathrm{X}_{31}$ & $\begin{array}{l}\text { Effectiveness of } \\
\text { specifications }\end{array}$ & $\begin{array}{c}\text { Mamat \& } \\
\text { Roslan (2012) }\end{array}$ \\
\hline & $\begin{array}{l}\text { Blue prints }(\mathrm{H} 18): \text { Blue } \\
\text { prints play major role in } \\
\mathrm{T} / \mathrm{T}\end{array}$ & $\mathrm{X}_{32}$ & $\begin{array}{l}\text { Effectiveness of blue } \\
\text { prints }\end{array}$ & $\begin{array}{l}\text { Hussain } \\
(2008)\end{array}$ \\
\hline & $\begin{array}{l}\text { Maintenance manuals } \\
\text { (H19): Maintenance } \\
\text { manuals play major role in } \\
\text { T/T }\end{array}$ & $\mathrm{X}_{33}$ & $\begin{array}{l}\text { Effectiveness of } \\
\text { maintenance } \\
\text { manuals }\end{array}$ & $\begin{array}{l}\text { Dasanayaka \& } \\
\text { Sadana (2010) }\end{array}$ \\
\hline & $\begin{array}{l}\text { Service manuals }(\mathrm{H} 20): \\
\text { Service manuals play } \\
\text { major role in } \mathrm{T} / \mathrm{T}\end{array}$ & $\mathrm{X}_{34}$ & $\begin{array}{l}\text { Effectiveness of } \\
\text { service manuals }\end{array}$ & $\begin{array}{c}\text { Dasanayaka \& } \\
\text { Jayarathna } \\
(2012) \\
\end{array}$ \\
\hline
\end{tabular}

According to Abobaker (2015), the factors which influenced on overall performance of the plant are taken as the major factors to investigate. In this study 34 factors were identified as the major components to be investigated after discussing with the industry experts and plant management. The priority elements were taken in the second step. Thirdly the identified factors were tested with the systems which have already been proven as successful following the literature and with the masterminds of ongoing projects. Finally, the success factors were compared and contrasted with the pre-defined success criteria (Purushotham, 2015). Accordingly, 34 factors which are directly involved with the project were taken for further study. 


\section{Data analysis and discussion}

Thirty-Four variables were measured with 5 point Likert scale in order to find the influence of each identifier to the successfulness of the project. According to the findings of the research, following descriptive and inferential statistics were reached. The completed questionnaires were further studied using SPSS 23.0. The steps involved in data analysis were composed of data collection, coding, error correction, compensation on missing data, checking of normality, linearity, outliers, multi co-linearity, factor analysis, descriptive and inferential analysis etc. With the use of structured questionnaire, different levels of the management of NCPP were monitored and findings were analysed. In order to find out critical success factors from 34 identifiers, hypothesis testing was carried out using one sample t-test and results were given in Table 2 . The factors on which null hypothesis have rejected were selected as the critical success factors on technology transfer. Further, factor analysis was performed to identify factors with high correlations and thereby remove redundancies and then identify the major parameters for effective technology transfer.

According to the research findings, the successfulness of international technology transfer in Sri Lanka depends on 14 critical success factors. The quality of equipment $\left(\mathrm{X}_{5}\right)$ is directly related to the cost of equipment $\left(\mathrm{X}_{6}\right)$ and there is a significant correlation between those two parameters. Therefore, financial barrier prevailing in the country has moved the NCPP from Japanese technology to Chinese technology which has been found as a critical factor. The political barriers in the country have moved NCPP away from its expected scale of operation due to various objections imposed by different pressure groups. As a result, several most suitable locations had been thrown away due to security reasons as well as environmental concerns. Hence, environmental soundness $\left(\mathrm{X}_{15}\right)$ and location of the project is one of the other critical factor identified within this study. As a result, the six-month difficulty in coal transporting near the NCPP coast prevails due to heavy sea waves, experiencing from May to September during the West-South monsoon rain period of every year.

Transferor's skills $\left(\mathrm{X}_{16}\right)$, transferor's supporting staff skills $\left(\mathrm{X}_{17}\right)$ and transferor's expertise on similar projects $\left(\mathrm{X}_{22}\right)$ have become other significant critical factors. Effectiveness of transferee's technology awareness and different practices $\left(\mathrm{X}_{29}\right)$ has become another critical factor to harness the best options available with the transferor. Initially, CEB employed a consultant for this turnkey project and the capacity and expertise of the consultant has major influence on the successfulness of the entire work. This is obvious in NCPP, that many carbon sequestration practices $\left(\mathrm{X}_{24}\right),\left(\mathrm{X}_{25}\right)$, clean coal technologies, carbon capture and storage mechanisms, effective fly ash and bottom ash handling techniques $\left(\mathrm{X}_{11}\right)$, $\left(\mathrm{X}_{30}\right),\left(\mathrm{X}_{31}\right)$ have some issues in NCPP due to the lack of consultant's awareness during negotiation stage. 
Table 2. Data analysis and identified critical success factors

\begin{tabular}{|c|c|c|c|c|}
\hline Concept & Indicator & Identifier & $\begin{array}{l}\text { Confidence } \\
\text { level } \\
\alpha=0.05, H_{0}: \\
\mu_{0}=3.660 \\
H_{0} \text { Rejected } \\
(\text { Yes } / \text { No) }\end{array}$ & Rank \\
\hline \multirow[t]{3}{*}{$\begin{array}{l}\text { Technoware } \\
\text { (C1) }\end{array}$} & Equipment (H2) & $\begin{array}{l}\mathrm{X}_{5}-\text { Quality of } \\
\text { Equipment }\end{array}$ & Yes & 2 \\
\hline & $\begin{array}{l}\text { Scale of operation } \\
\text { (H4) }\end{array}$ & $\begin{array}{l}\mathrm{X}_{11^{-}} \\
\text {Appropriateness of } \\
\text { operation }\end{array}$ & Yes & 10 \\
\hline & $\begin{array}{l}\text { Environmental } \\
\text { soundness of } \\
\text { operation (H8) }\end{array}$ & $\begin{array}{l}\mathrm{X}_{15}-\text { Environmental } \\
\text { soundness of } \\
\text { operation }\end{array}$ & Yes & 1 \\
\hline \multirow[t]{3}{*}{$\begin{array}{l}\text { Humanware } \\
\text { (C2) }\end{array}$} & Skills (H9) & $\begin{array}{l}\mathrm{X}_{16}-\text { Transferor } \\
\text { skills }\end{array}$ & Yes & 8 \\
\hline & & $\begin{array}{l}\mathrm{X}_{17-} \text { transferor } \\
\text { supporting staff } \\
\text { skills }\end{array}$ & Yes & 9 \\
\hline & Expertise (H11) & $\begin{array}{l}\mathrm{X}_{22} \text { - Transferor } \\
\text { expertise }\end{array}$ & Yes & 7 \\
\hline \multirow[t]{3}{*}{$\begin{array}{l}\text { Orgaware } \\
\text { (C3) }\end{array}$} & Methods (H12) & $\begin{array}{l}X_{24}-\text { Effectiveness of } \\
\text { methods }\end{array}$ & Yes & 11 \\
\hline & Techniques (H13) & $\begin{array}{l}\mathrm{X}_{25} \text { - effectiveness } \\
\text { of techniques }\end{array}$ & Yes & 6 \\
\hline & Practices (H15) & $\begin{array}{l}\mathrm{X}_{28} \text { - Effectiveness of } \\
\text { transferor practices }\end{array}$ & Yes & 5 \\
\hline \multirow[t]{5}{*}{ Infoware (C4) } & & $\begin{array}{l}\mathrm{X}_{29} \text { - Effectiveness of } \\
\text { transferee practices }\end{array}$ & Yes & 12 \\
\hline & $\begin{array}{l}\text { Design parameters } \\
(\mathrm{H} 16)\end{array}$ & $\begin{array}{l}\mathrm{X}_{30^{-}} \text {effectiveness of } \\
\text { design parameters }\end{array}$ & Yes & 3 \\
\hline & Specifications (H17) & $\begin{array}{l}\mathrm{X}_{31} \text { - Effectiveness of } \\
\text { design } \\
\text { specifications }\end{array}$ & Yes & 4 \\
\hline & $\begin{array}{l}\text { Maintenance } \\
\text { manuals (H19) }\end{array}$ & $\begin{array}{l}\mathrm{X}_{33} \text { - Effectiveness of } \\
\text { maintenance } \\
\text { manuals }\end{array}$ & Yes & 13 \\
\hline & Service manuals (H20) & $\begin{array}{l}\mathrm{X}_{34}-\text { Effectiveness of } \\
\text { service manuals }\end{array}$ & Yes & 14 \\
\hline
\end{tabular}

Further, many of the key operational activities have still been handling by the Chinese experts creating poor technology transfer mechanism as identified by poor maintenance manuals $\left(\mathrm{X}_{33}\right)$, poor service manuals $\left(\mathrm{X}_{34}\right)$, poor training programs, in effective communication or communication barriers, transferor's reluctance to transfer the technology fully to local engineers etc. have been identified as rest of the critical factors within this study. Finally, 14 factors were found as critical and same is compared with respect to the NCPP and verified their successfulness and failures. 


\section{Conclusion and policy recommendations}

Although 34 numbers of variables have been identified as the main influencing factors on international technology transfer of a country (Abobaker, 2015), many are trivial and redundant when compared to the social, environmental and financial constraints are concerned. Therefore, scale of operation, environmental soundness, skills, expertise, methods, techniques and practices of both transferor and transferee are critical and important during this exercise. Further, design, specifications, of the plant, maintenance manuals and service manuals of the equipment have been identified as the critical components of this business. The most important factor which has been unearthed from this study was whether the plant capacity is properly matched with the Sri Lankan network capacity. The total load center in CEB is located mostly in western province and the country's maximum demand is about 2400MW in year 2017 as per the Long Term Generation Expansion Plan (LTGEP) 20172038 of CEB. Accordingly, 300x3MW power from NCPP transmits with limited transmission capacity of $115 \mathrm{~km}$ line along the coastal belt and inland vegetation from Norochcholai to Veyangoda Grid Sub Station (GSS), which creates frequent failures while paralyzing the entire country's power supply which is the failure during technology transfer stage. When considering the environmental impact with respect to NCPP, environmental friendly coal storage, avoiding ground water contamination, creating wind barriers to coal dust and fly ash, extending the backup zone with proper vegetation to neutralize the abnormal air conditions, releasing the heated water with reduced temperature with enhanced purification with chemicals are main factors which have been less concerned at the technology transfer stage. Now CEB is at the verge of building 14metre height wind barrier to protect the environment, livelihood, farmlands and inhabitants in the surroundings from moving fly ash and coal dust due to strong sea waves and heavy monsoon winds.

The next important factors as identified during the study are skills, experience and methods which are governed mainly from the transferor's side. For an example, the Chinese to English interpreter has made an important role during the technology transfer stage. It was found during the discussion with the NCPP staff that interpreter's role is dominant on diffusing the new technology. Many Chinese interpreters know only English but not the subject matter. As a result, they are translating the word by word but neglecting the whole meaning of the scenario. Further, many operating manuals are in Chinese language and even onsite instructions have been written in Chinese language. These things are very critical in this kind of technology transfer activity.

International technology transfer helps to enhance the human life spending while making successful financial, social and environmental gains. However, whenever the technology is inviting to a country, it must be well studied, equally balanced and environmentally friendly in the long run. Therefore, identified critical success factors are to be well concerned whenever the technology transfer is performing among developed and 
developing countries. The financial concern must not be compromised on other critical factors as long as the developing countries are concerned. The national policy on international technology transfer must be based on 14 critical success factors identified on this study. Since, NCPP is the very first plant in Sri Lanka, critical factors identified above have not been considered fully and as a result several processes such as waste disposal, and recycling or use for any other activities have not been studied fully by the consultants and same has not been transferred fully.

Since the coal power industry is very new to our Country, it is very important to study the critical success factors of existing coal power plants in any other country in order to better understand the major issues prevailing with this business in detail. This prevails as a future study. Further, the consideration of the capability and experiences of the transferee's consultant is very important while streamlining of project consultants who have made many mistakes during the implementation of this entire project. Transferor entrusted contractors are also to be well experienced in similar projects and it is the responsibility of the transferee's consultant to get the most out of the investment. In NCPP it is observed that utilization of bottom ash and flying ash at primitive stage. Many developed countries use clean coal technologies, integrated gasification, carbon sequestration, super critical and even ultra-super critical boiler technologies to ensure the environmental safety as well as to achieve higher thermal efficiency which are to be highly concerned in the future coal power stations in Sri Lanka.

\section{References}

Abobaker, S. (2015). The key success factors in international technology transfer in Egypt and Libya. Doctoral Thesis. The University of Gloucestershire, Cheltenham: England.

Martyniuk, A. O., Jain, R. K. \& Stone, H. J. (2003). Critical success factors and barriers to technology transfer: case studies and implications. International Journal of Technology Transfer and Commercialization, 2(3), 306-327.

Bell, M. (1997). Technology transfers to transition countries: are there lesions from experience post-war industrializing countries? In Dyker, D.A. (Eds), The Technology of Transition. Central University Press, Budapest.

Dasanayaka, S., \& Sadana, G (2010). Development of SME through Clusters and Networking: a comprehensive study of India, Pakistan and Sri Lanka. World Review of Entrepreneurship, Management \& Sustainable Development, InderScience, 6(1\&2), 50-72.

Dasanayaka, S., \& Jayarathna, W. (2012). Economics feasibility of carbon emission reduction in electricity generation, a case study based on Sri Lanka. International Journal of Global Warming, 4(2), 142-178.

Mamat, F. B., \& Roslan, S. B. (2012). Critical success factors on technology transfer effectiveness in manufacturing industry: a critical review, International journal of business economics and law, 1, 163-170. 
Hussain, A. (2008). Analysis of international technology transfer experience in Ceylon Electricity Board and development of technology transfer model. Unpublished MBA Dissertation, University of Moratuwa, Sri Lanka.

Khan, S. (2005). Technology transfer effectiveness through international joint ventures to their component suppliers: a study of automotive industry of Pakistan. Unpublished Doctoral Thesis, University of Birmingham, United Kingdom.

Kumaraswamy, M. (2003). Determining the success of failure of international technology transfer: a conceptual framework, Industry and higher education. 17(1), 51-57.

Abbaslu, L. \& Yaghoubipoor, A. (2015). Identify and categorize indicators of technology transfer in Kerman Copper Company. International Research Journal of Management Sciences. 3(10), 517-523.

Dameno, E. \& Lopez, P. Q. (2015). Critical success factors for electricity generation projects using $L N G$. Retrieved from http://www.gastechnology.org/Training/Documents/LNG17proceedings/10-4-Pablo_Lopez.pdf.

Pazhand, H. 2009). Cleaner coal technologies and technology transfer: Institute of Energy Research Systems-Analysis and Technology Evaluation (IEF-STE), Germany. Retrieved from http://www.fzjuelich.de/SharedDocs/Downloads/IEK/IEK-

STE/EN/Student\%20Research\%20Report\%2005_2009.pdf?_blob=p ublicationFile.

Purushotham, H., Vithiyanathan, S., Sunder, S. (2015). Structural Equation Modeling (SEM) approach to identify the critical success factors of technology transfer. Advances in Industrial Engineering and Management, 4(2), 123-146.

Ramanathan, K. (1994). The polytrophic components of manufacturing technology. Technological Forecasting and social change, 46, 221-258.

Tan, R. (1996). Success criteria and success factors for external technology transfer projects. Project Management Journal, 27(2), 4556. 